\title{
A Study of Certain Heterotrophic Polarly Flagellate Water Bacteria: Aeromonas, Pseudomonas and Comamonas
}

\author{
By R. W. A. PARK* \\ Department of Bacteriology, University of Birmingham
}

(Received 3 May 1961)

SUMMARY

Sixty-one polarly flagellate bacteria, initially identified as such by the type of motility they displayed, were isolated from surface waters and classified on the basis of cultural and biochemical tests into three genera: Aeromonas, Pseudomonas, Comamonas. Sixteen similarly flagellated cultures from other sources were also found to be members of these genera. Some bacteria with a single polar flagellum and giving reactions of the Alcaligenes type were isolated. It is suggested that the definition of the genus Comamonas (Davis \& Park) be extended to include such forms. The possibility of confusing Aeromonas with Vibrio and with some enterobacteria is discussed.

\section{INTRODUCTION}

Although much research into the bacteriology of sea water has been carried out recently there has been little corresponding work on the bacteriology of surface waters, with the exception of studies concerned primarily with public health. Reports on water bacteria made by Ward (1897), Boyce \& Hill (1900), Taylor (1942), Thomas \& Thomas (1955) and Corberi \& Solaini (1960) gave no mention of flagellation or motility in the strains studied, while those of Fuller \& Johnson (1899), Jordan (1903) and Cornwall (1914) recorded motility but not flagellation. In fact, so far as the author is aware, only one study on the range of bacteria present in surface waters has included an examination of flagellar pattern (Gray, 1951) but neither the method of determination nor the detailed results obtained were recorded. Therefore, while there is considerable information available about the types of bacteria present in surface waters, it is of limited taxonomic value because the flagellar pattern of strains, a characteristic of importance in current taxonomy, has not been recorded. Shewan, Floodgate \& Hayes (1958) noted a similar lack of information in the literature about sea-water bacteria.

Our knowledge of the polarly flagellate Gram-negative bacteria is being increased by studies concerned with the identification and internal classification of one, or sometimes of two genera (Haynes, 1951 ; Miles \& Miles, 1951; Galarneault \& Leifson, 1956; Wetmore \& Gochenour, 1956; Rhodes, 1959; Eddy, 1960), and by the development of simple methods for differentiating polarly flagellate from peritrichously flagellate and non-motile forms, and for separating polarly flagellate forms into genera (Shewan, Hodgkiss \& Liston, 1954; Ewing \& Johnson, 1960). However, if a satisfactory classification of the Gram-negative rods is to be achieved, more

\footnotetext{
* Present address : Department of Microbiology, The University of Reading, Reading, Berks.
} 
information about the range of types of polarly flagellate bacteria that exist, and about the relationships of these types with one another and with peritrichously flagellate and non-motile bacteria, will have to be obtained. It was thought that a study of polarly flagellate bacteria isolated from surface waters would supply additional information on the flora of this habitat and would enable an assessment to be made of the taxonomic value of a range of biochemical tests when applied to this group.

\section{METHODS}

\section{Isolation and recognition of polarly flagellate bacteria}

Water samples were taken from ditches, streams and rivers in $100 \mathrm{ml}$. sterile screw-cap bottles. The bottles were plunged into the water and pushed in the direction of the neck so as to avoid contamination from the hands. Samples were returned to the laboratory within $2 \mathrm{hr}$. and 3 loopfuls $(4 \mathrm{~mm}$. diam.) were removed and spread on each of 2 nutrient agar plates, which were then incubated at $30^{\circ}$ for 3 days. At the end of this period samples from several colonies of each colony type on the isolation plates were inoculated into tubes of peptone water $(\%, w / v$ : Oxoid

Table 1. Cultures received from other workers

\begin{tabular}{|c|c|c|}
\hline Number & Designation & Donor \\
\hline NCIB 6750 & Pseudomonas aeruginosa & $\begin{array}{l}\text { National Collection of Indus- } \\
\text { trial Bacteria (NCIB) }\end{array}$ \\
\hline NCIB 8178 & P. synxantha & NCIB \\
\hline NCIB 8295 & P. aeruginosa & NCIB \\
\hline NCIB 8297 & Pseudomonas sp. & NCIB \\
\hline NCIB 8298 & Pseudomonas sp. & NCIB \\
\hline NCIB 8529 & P. hydrophila & NCIB \\
\hline NCIB 8580 & P. hydrophila & NCIB \\
\hline NCIB 8615 & $P \cdot$ putrefaciens & NCIB \\
\hline $\mathbf{4 1}$ & $P$. aeruginosa (?) from human faeces & Dr E. B. Pike \\
\hline 42 & $P$. aeruginosa (?) from human faeces & Dr E. B. Pike \\
\hline 78 & P. aeruginosa (?) from cockroach gut & Mrs E. Healey \\
\hline 79 & P. aeruginosa (?) from cockroach gut & Mrs E. Healey \\
\hline 80 & $P$. aeruginosa (?) from human mouth & Dr A. C. Baird-Parker \\
\hline 81 & $P$. aeruginosa (?) from human mouth & Dr A. C. Baird-Parker \\
\hline 98 & Gram-negative rod from carious tooth & Dr A. C. Baird-Parker \\
\hline 100 & Gram-negative rod from carious tooth & Dr A. C. Baird-Parker \\
\hline
\end{tabular}

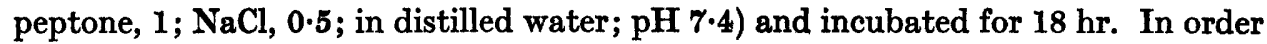
to have a comparison with bacteria from other habitats, several cultures listed in Table 1 were treated in the same way. In addition 14 Vibrio cultures were studied: the work on these was recorded by Davis \& Park (1961). After incubation cultures were examined by the hanging drop method. Those cultures judged by their straight darting movement of the order of $40 \mu / \mathrm{sec}$. to consist of polarly flagellate bacteria were subcultured on nutrient agar to test their purity and then maintained as described by Davis \& Park (1961). The flagellation of all the 61 water strains and the 16 strains from other sources was confirmed by electron microscopy. Five cultures which showed zig-zag motion of the order of $10 \mu / \mathrm{sec}$. or less were also retained for electron microscopy. 


\section{Determination of morphological cultural and biochemical characteristics}

The tests carried out to determine these characteristics were described by Davis \& Park (1961).

\section{Flagellation and morphology}

\section{RESULTS}

All the strains considered to be polarly flagellate because they displayed a straight darting movement were found to have polar flagella and to be Gram-negative. Somatic curvature was a common feature of certain strains of Pseudomonas fluorescens, Comamonas and Aeromonas. Neither $S$-forms, spirals or spheroplasts, all considered by Park (1961) and Davis \& Park (1961) to be characteristic of members of the genus Vibrio, were observed. Cultures of some Comamonas strains included long forms. These were either non-flagellate or had flagella at the poles only. Similar forms, with a different type of flagellation, were reported in Comamonas cultures by Galarneault \& Leifson (1956). Of the five strains which showed the kind of motility believed to be associated with peritrichous flagellation (i.e. $\dot{\text { zig-zag }}$ motion of the order of $10 \mu /$ sec. or less) four were found to display typical peritrichous flagellation, while the fifth possessed the flagellation described by Conn \& Wolfe (1938) as 'degenerate peritrichous'; this strain had one flagellum arising from some point other than the pole ( $\mathrm{Pl}$. 1, fig. 3).

Variations in the number of flagella possessed by organisms of a single culture were observed: a finding similar to those of Bartholomew (1949) and of Rhodes (1958). There was, however, some indication that the degree of variation was reasonably consistent within a group of strains. All of the Comamonas, 12 of the 14 Aeromonas and 9 of the 10 Pseudomonas aeruginosa (P. pyocyanea) strains consisted chiefly of organisms with a single polar flagellum, though some with 2 polar flagella were also present (Pl. 1, figs. 1, 4). In contrast, 22 of the $30 P$. fluorescens strains displayed from 1 to 10 flagella/organism (Pl. 1, fig. 7).

Bipolar flagellation was never detected in any of the strains examined. This was in marked contrast to the experience of Park (1961) and Davis \& Park (1961) with Vibrio spp. and with $V$. neocistes and $V$. cyclosites. However, other workers have reported bipolar flagellation in Pseudomonas (Lehmann \& Neuman, 1981; Bisset, 1951 ; Rhodes, 1958) and in Comamonas (Galarneault \& Leifson, 1956).

The flagellation of the two Aeromonas hydrophila strains differed markedly from that of other strains classified as Aeromonas. Both strains consisted of organisms which had several long thin flagella that appeared to arise from any point on the body (Pl. 1, fig. 6, 8). These strains displayed the kind of motility associated with polarly flagellate bacteria.

\section{Attack on carbohydrates}

Certain Comamonas strains brought about a decrease in the $\mathrm{pH}$ value of carbohydrate-free peptone water and therefore in most of the carbohydrate-containing peptone water media. However, some strains did not do this in the presence of sucrose or maltose. Acidification of the carbohydrate-free peptone water medium was not brought about by any of the Pseudomonas or Aeromonas cultures. It is obvious that control tubes should be used in carbohydrate tests carried out in peptone water (see Orcutt \& Nutting, 1942). No strains acidified the basal medium of 
Simon (1956); fermentation results in this medium were the same as those in peptone water.

Four Comamonas strains were able to utilize certain carbohydrates as sole carbon source but they produced no acid from these compounds in complex media. Similar strains were reported by Khambata \& Bhat (1953) and by Pivnick (1955).

All but one of the Comamonas strains produced an alkaline reaction in the Hugh \& Leifson (1953) open tube. This reaction was restricted to the surface at $24 \mathrm{hr}$. but it often spread throughout the tube within 7 days. Two of the 4 strains that had been found to utilize glucose and some other carbohydrates as sole carbon source, although they produced an alkaline reaction at the surface of the open tube after $24 \mathrm{hr}$., showed a reversion to neutral at 7 days. Several Pseudomonas strains produced a little alkali in the open tube within $24 \mathrm{hr}$. but in every case an acid reaction had developed by 7 days. No changes were observed in the closed tubes inoculated with either Comamonas or Pseudomonas.

Table 2. Percentage of strains in each genus giving positive results to tests

\begin{tabular}{|c|c|c|c|}
\hline Test & $\begin{array}{l}\text { Aeromonas } \\
14 \text { strains }\end{array}$ & $\begin{array}{l}\text { Pseudomonas } \\
40 \text { strains }\end{array}$ & $\begin{array}{l}\text { Comamonas } \\
23 \text { strains }\end{array}$ \\
\hline $\begin{array}{l}\text { Somatic curvature of some organisms } \\
\text { More than } 3 \text { flagella/organism } \\
\text { Gas from carbohydrates }\end{array}$ & $\begin{array}{r}7 \cdot 1 \\
0 \cdot 0 \\
92 \cdot 9\end{array}$ & $\begin{array}{r}40 \cdot 0 \\
57 \cdot 5 \\
0 \cdot 0\end{array}$ & $\begin{array}{r}13 \cdot 0 \\
0.0 \\
0.0\end{array}$ \\
\hline $\begin{array}{l}\text { Acid in peptone water base }+ \text { : } \\
\text { arabinose } \\
\text { glucose } \\
\text { fructose } \\
\text { mannose } \\
\text { galactose } \\
\text { mannitol } \\
\text { dulcitol } \\
\text { sorbitol } \\
\text { sucrose } \\
\text { lactose } \\
\text { maltose } \\
\text { salicin }\end{array}$ & $\begin{array}{r}82.9 \\
100.0 \\
100 \cdot 0 \\
100 \cdot 0 \\
100 \cdot 0 \\
100 \cdot 0 \\
7 \cdot 1 \\
50.0 \\
92.9 \\
42.8 \\
100 \cdot 0 \\
71.4\end{array}$ & $\begin{array}{r}100 \cdot 0 \\
100 \cdot 0 \\
20.0 \\
100 \cdot 0 \\
100 \cdot 0 \\
27 \cdot 5 \\
0.0 \\
0.0 \\
17 \cdot 5 \\
0.0 \\
0.0 \\
0 \cdot 0\end{array}$ & $\begin{array}{l}0.0 \\
0.0 \\
0.0 \\
0.0 \\
0.0 \\
0.0 \\
0.0 \\
0.0 \\
0.0 \\
0.0 \\
0.0 \\
0.0\end{array}$ \\
\hline $\begin{array}{l}\text { Utilization as sole carbon source: } \\
\text { arabinose } \\
\text { glucose } \\
\text { fructose } \\
\text { mannose } \\
\text { galactose } \\
\text { mannitol } \\
\text { dulcitol } \\
\text { sorbitol } \\
\text { sucrose } \\
\text { lactose } \\
\text { maltose } \\
\text { salicin }\end{array}$ & $\begin{array}{r}92.9 \\
100.0 \\
100 \cdot 0 \\
100.0 \\
100.0 \\
100.0 \\
0.0 \\
50.0 \\
92.9 \\
42.8 \\
100.0 \\
71.4\end{array}$ & $\begin{array}{r}100.0 \\
100 \cdot 0 \\
20.0 \\
100.0 \\
100 \cdot 0 \\
47 \cdot 5 \\
0.0 \\
0.0 \\
17 \cdot 5 \\
0.0 \\
0.0 \\
0.0\end{array}$ & $\begin{array}{r}0.0 \\
17 \cdot 4 \\
8.7 \\
0.0 \\
17 \cdot 4 \\
8.7 \\
0.0 \\
0.0 \\
0.0 \\
0.0 \\
0.0 \\
0.0\end{array}$ \\
\hline $\begin{array}{l}\text { Fermentation of glucose (Hugh \& Leifson) } \\
\text { Oxidation of glucose (Hugh \& Leifson) }\end{array}$ & $\begin{array}{c}100 \cdot 0 \\
?\end{array}$ & $\begin{array}{r}0 \cdot 0 \\
100 \cdot 0\end{array}$ & $\begin{array}{l}0.0 \\
0 \cdot 0\end{array}$ \\
\hline Reducing compounds from gluconate & $79 \cdot 0$ & $92 \cdot 5$ & 0.0 \\
\hline $\begin{array}{l}\text { Acetoin production } \\
\text { Methyl red test }\end{array}$ & $\begin{array}{r}92 \cdot 9 \\
0 \cdot 0\end{array}$ & $\begin{array}{l}\mathbf{0 \cdot 0} \\
\mathbf{0 \cdot 0}\end{array}$ & $\begin{array}{l}0 \cdot 0 \\
0 \cdot 0\end{array}$ \\
\hline Modified Eijkman test & 0.0 & $0 \cdot 0$ & $0 \cdot 0$ \\
\hline
\end{tabular}


Table 2 (cont.)

\begin{tabular}{|c|c|c|c|}
\hline Test & $\begin{array}{l}\text { Aeromonas } \\
\text { 14, strains }\end{array}$ & $\begin{array}{l}\text { Pseudomonas } \\
40 \text { strains }\end{array}$ & $\begin{array}{l}\text { Comamonas } \\
23 \text { strains }\end{array}$ \\
\hline $\begin{array}{l}\text { Starch hydrolysis } \\
\text { Nitrate reduction }\end{array}$ & $\begin{array}{r}79 \cdot 0 \\
100 \cdot 0\end{array}$ & $\begin{array}{l}30.0(W) \\
32.5\end{array}$ & $\begin{array}{r}0 \cdot 0 \\
47 \cdot 8\end{array}$ \\
\hline $\begin{array}{l}\text { Nitrate reduction } \\
\text { Cholera red reaction }\end{array}$ & $\begin{array}{r}100 \cdot 0 \\
0 \cdot 0\end{array}$ & $\begin{array}{r}32 \cdot 5 \\
0 \cdot 0\end{array}$ & $\begin{array}{r}47 \cdot 8 \\
0 \cdot 0\end{array}$ \\
\hline Indole production & $\begin{array}{r}0.0 \\
71 \cdot 4\end{array}$ & $\begin{array}{l}0.0 \\
0.0\end{array}$ & $\begin{array}{l}0 \cdot 0 \\
0 \cdot 0\end{array}$ \\
\hline \multicolumn{4}{|l|}{ Utilization as sole carbon source of: } \\
\hline tryptophan & $7 \cdot 1$ & $57 \cdot 5$ & 13.0 \\
\hline phenylalanine & 0.0 & $95 \cdot 0$ & $17 \cdot 4$ \\
\hline phenol & $0 \cdot 0$ & $20 \cdot 0$ & $0 \cdot 0$ \\
\hline benzoic acid & $7 \cdot \mathbf{1}$ & 72.5 & $\mathbf{0 \cdot 0}$ \\
\hline catechol & $7 \cdot 1$ & $47 \cdot 5$ & 0.0 \\
\hline \multicolumn{4}{|l|}{ Attack on: } \\
\hline tyrosine & 64.3 & 97.5 & $\mathbf{8 7 \cdot 0}$ \\
\hline phenylalanine (Shaw \& Clarke) & 0.0 & $10 \cdot 0$ & $4 \cdot 4$ \\
\hline malonate (Shaw \& Clarke) & $\mathbf{7 1 \cdot 4}$ & $100 \cdot 0$ & 56.5 \\
\hline gelatin & $100 \cdot 0$ & $72 \cdot 5$ & $39 \cdot 1$ \\
\hline serum & $64 \cdot 3$ & $27 \cdot 5$ & $0 \cdot 0$ \\
\hline casein & $57 \cdot 1$ & $27 \cdot 5$ & $17 \cdot 4$ \\
\hline $\mathrm{H}_{8} \mathrm{~S}$ from peptone & $100 \cdot 0$ & $22 \cdot 5$ & $52 \cdot 2$ \\
\hline Urea hydrolysis & $21 \cdot 4$ & 67.5 & $4 \cdot 4$ \\
\hline Tributyrin hydrolysis & $100 \cdot 0$ & $100 \cdot 0$ & $100 \cdot 0$ \\
\hline \multicolumn{4}{|l|}{ Utilization as sole carbon source of: } \\
\hline succinate & $100 \cdot 0$ & $100 \cdot 0$ & $69 \cdot 6$ \\
\hline malate & $100 \cdot 0$ & $100 \cdot 0$ & $60 \cdot 9$ \\
\hline acetate & 92.9 & $100 \cdot 0$ & $65 \cdot 2$ \\
\hline citrate & $100 \cdot 0$ & $100 \cdot 0$ & $60 \cdot 9$ \\
\hline pyruvate & $\mathbf{9 2 \cdot 9}$ & $100 \cdot 0$ & $69 \cdot 6$ \\
\hline lactate & $28 \cdot 6$ & $100 \cdot 0$ & $69 \cdot 6$ \\
\hline malonate & $21 \cdot 4$ & $100 \cdot 0$ & $\mathbf{3 4} \cdot \mathbf{8}$ \\
\hline formate & $7 \cdot 1$ & $90 \cdot 0$ & $\mathbf{4 3 \cdot 4}$ \\
\hline ethanol & 0.0 & $90 \cdot 0$ & $\mathbf{3 9 \cdot 1}$ \\
\hline Catalase production & $100 \cdot 0$ & $100 \cdot 0$ & $100 \cdot 0$ \\
\hline Kovacs oxidase test & $57 \cdot 1$ & $\mathbf{9 0 \cdot 0}$ & $56 \cdot 5$ \\
\hline Cytochrome oxidase test & $57 \cdot 1(L)$ & $\begin{array}{c}90.0 \\
(+\& L)\end{array}$ & $\begin{array}{c}56 \cdot 5 \\
(+\& L)\end{array}$ \\
\hline \multicolumn{4}{|l|}{ Growth at: } \\
\hline $0^{\circ}$ & $100 \cdot 0$ & 52.5 & $\mathbf{3 0 \cdot 4}$ \\
\hline $\mathbf{3 7}^{\circ}$ & 92.9 & $\mathbf{8 0 . 0}$ & $95 \cdot 6$ \\
\hline $\mathbf{4 2}^{\circ}$ & $21 \cdot 4$ & $25 \cdot 0$ & 34.8 \\
\hline $45^{\circ}$ & $\mathbf{0} \cdot \mathbf{0}$ & $\mathbf{2 5} \cdot 0$ & $13 \cdot 0$ \\
\hline \multicolumn{4}{|l|}{ Growth in presence of: } \\
\hline $1 \%(w / v) ~ N a C l$ & $100 \cdot 0$ & $100 \cdot 0$ & $100 \cdot 0$ \\
\hline $3 \%(w / v) ~ N a C l$ & $71 \cdot 4$ & 95.0 & $91 \cdot 3$ \\
\hline $6 \%(\mathrm{w} / \mathrm{v}) \mathrm{NaCl}$ & 14.3 & $\mathbf{2 5 \cdot 0}$ & $\mathbf{2 1} \cdot \mathbf{7}$ \\
\hline $9 \%(w / v) \mathrm{NaCl}$ & $0 \cdot 0$ & 0.0 & $4 \cdot 4$ \\
\hline \multicolumn{4}{|l|}{ Growth on: } \\
\hline MacConkey's agar & $\mathbf{8 5 \cdot 7}$ & $77 \cdot 5$ & $\mathbf{7 3 \cdot 9}$ \\
\hline Aronson's agar & $\mathbf{2 8 \cdot 6}$ & 0.0 & $52 \cdot 2$ \\
\hline Production of u.v.-fluorescent compounds & $\mathbf{0 . 0}$ & $100 \cdot 0$ & 0.0 \\
\hline \multicolumn{4}{|l|}{ Sensitivity to: } \\
\hline penicillin (2.5 i.u.) & $\begin{array}{r}0 \cdot 0 \\
100 \cdot 0\end{array}$ & $\begin{array}{r}\mathbf{0 . 0} \\
\mathbf{5 2 . 5}\end{array}$ & $\begin{array}{r}0 \cdot 0 \\
100 \cdot 0\end{array}$ \\
\hline $\begin{array}{l}\text { terramycin }(10 \mu \mathrm{g} .) \\
\text { streptomycin }(80 \mu \mathrm{g} .)\end{array}$ & $\begin{array}{l}100 \cdot 0 \\
100 \cdot 0\end{array}$ & $100 \cdot 0$ & $78 \cdot 3$ \\
\hline $\begin{array}{l}\text { streptomycin (80 } \mu \mathrm{g} .) \\
\text { chloramphenicol (100 } \mu \mathrm{g} .)\end{array}$ & $100 \cdot 0$ & $\mathbf{8 0 \cdot 0}$ & $95 \cdot 6$ \\
\hline compound $0 / 129$ & $\mathbf{0 . 0}$ & $\mathbf{0 . 0}$ & $\mathbf{0} \cdot \mathbf{0}$ \\
\hline
\end{tabular}

$\mathrm{W}=$ weak activity $\mathbf{L}=$ delayed reaction. 


\section{Utilization of ethanol}

Utilization of ethanol as a sole carbon source was a property displayed by all but 4 of the Pseudomonas strains studied. All the Pseudomonas aeruginosa strains and 7 of the $\boldsymbol{P}$. fluorescens strains brought about a clearing of the chalk medium, indicating that excess acid had been produced. Nine Comamonas strains utilized ethanol, 2 producing excess acid. None of the Aeromonas strains were active in this respect. It should be emphasized that this test is not the same as the 'acid in ethanol $+\mathrm{CaCO}_{3}$ agar' test of Shimwell, Carr \& Rhodes (1960) whose medium, which was recommended for the differentiation of Acetomonas and Pseudomonas, contains a higher concentration of ethanol and $\mathrm{CaCO}_{3}$ and also $1 \%(w / v)$ yeast extract.

\section{Production of fluorescent compounds}

Four of the strains identified as Pseudomonas were never seen to produce fluorescin. However, these 4 and all the other members of this genus, but no other strains, produced compounds which fluoresced under a source of ultraviolet radiations (u.v.) when they were grown on glucose + chalk medium or in the medium of Georgia \& Poe (1931).

\section{Details of results}

The complete details of results are not given here; those interested may obtain them from the author. The percentage of strains in each group which reacted positively to the various tests is given in Table 2.

\section{DISCUSSION}

All the $\mathbf{7 7}$ polarly-flagellate rod-shaped bacteria examined in this study were classifiable into one of three main groupings. While it is difficult, if not impossible, to define each of these groups in an exclusive manner, as is probably the case with all groups of bacteria (Sneath, 1957), the author feels that the characters of each of these groups given below are sufficient to allow their differentiation in practice.

Aeromonas. Fermentative attack on carbohydrates shown in Hugh \& Leifson's medium. No pigments or u.v.-fluorescent compounds produced.

Pseudomonas. Oxidative attack on carbohydrates displayed in Hugh \& Leifson's medium. Diffusible compounds that fluoresce under u.v. radiation produced on glucose + chalk medium, in the medium of Georgia \& Poe and on several other media. Pigments visible in daylight are not produced by all strains.

Comamonas. No attack on carbohydrates shown in complex media. Usually unable to utilize carbohydrates as sole carbon sources. No pigments or u.v.fluorescent compounds produced.

The distribution between the three genera of 'other features can be seen in Table 2.

\section{Aeromonas}

Eleven of the 14 strains included in Aeromonas were almost identical. The two type strains of $A$. hydrophila and strain 137 (author's no.) were exceptions. None 
of the Aeromonas strains isolated from water were seen to have other than true polar flagellation, in contrast to both strains of $A$. hydrophila (see Results). Miles \& Halnan (1937) and Kulp \& Borden (1942) reported that Aeromonas organisms had only one polar flagellum, but Miles \& Miles(1951) found that some had as many as eight. Leifson \& Hugh (1953) reported that in young cultures peritrichously flagellate organisms were often present. Strain 137 differed from the other Aeromonas strains in not producing gas during carbohydrate fermentation. It also differed in being Voges-Proskauer negative and in utilizing various aromatic compounds as sole carbon source. The strain was very similar to $A$. formicans described by Crawford (1954) and by Pivnick \& Sabina (1957). It was, however, methyl red negative, incapable of growth at $42^{\circ}$ and it fermented arabinose. A strain similar to no. 187 was isolated from tap water on Dieudonné's medium by Dr G. H. G. Davis (personal communication).

Several fermentative rod-shaped bacteria with polar flagella have been described and it is possible that even more kinds might have been, had flagellar pattern determination been a simpler process than it is. Following Kluyver \& van Niel (1936) the strains producing 2:3 butylene glycol as an end-product of glucose fermentation and therefore also giving a positive Voges-Proskauer reaction are known as Aeromonas, while those known to ferment carbohydrates with the production of ethanol are placed in a separate genus, Zymomonas. Strains that showed a typical Escherichia coli fermentation except for the fact that gases were not produced were classified as Aeromonas by Pivnick \& Sabina (1957) since these authors considered that all fermentative pseudomonads except Zymomonas should, temporarily at least, be included in a single genus. The present author feels that it would be more satisfactory to include all polarly flagellate rod-shaped fermentative bacteria in a single genus, Aeromonas, with specific rank being given to strains which show different end-products of fermentation. He considers that the ability to ferment carbohydrates is a more basic characteristic than is the production of a particular endproduct of fermentation. Stevenson's (1959) suggestion that Aeromonas strains are in reality non-pigmented Serratia has been shown to be not acceptable (Eddy, 1960; Liu, $1961 a$ ). For a more detailed discussion of the genus Aeromonas the reader is referred to Eddy (1960).

When only cultural and biochemical characters are studied there is a risk of classifying Aeromonas bacteria as members of the Enterobacteriaceae (Crawford, 1954; Eddy, 1960; Ewing \& Johnson, 1960). Certainly one cannot rely on the test used by Thomas, Hobson \& Druce (1959) and others (i.e. the ability to produce acid and gas in lactose MacConkey broth within 5 days at $\left.30^{\circ}\right)$ to diagnose coli-aerogenes bacteria, since Aeromonas strains which react positively in the test are known (Eddy \& Kitchell, 1959). In fact, in the present state of our knowledge it seems wise to determine the flagellar pattern of any Gram-negative rod that is being classified. Because the determination of flagellar pattern is difficult and time-consuming, and because the classification of non-flagellate forms and forms which show a variation in the type of flagellation they display (Leifson \& Hugh, 1958; Sneath, 1956; Adams, Williams \& Payne, 1961) is not helped by such a determination, biochemical tests that will enable one to separate the polarly flagellate group from the peritrichously flagellate group are needed. The tests concerned with arginine metabolism (Sherris, Shoesmith, Parker \& Breckon, 1959; Thornley, 1960), and the 
modified cytochrome oxidase test (Ewing \& Johnson, 1960), in which only polarly flagellate rods give positive results, are promising in this respect. It should be noted that the Aeromonas strains studied in the present work gave late or negative results in the original form of the cytochrome oxidase test.

It would seem to be a logical step to unite Vibrio comma and closely related organisms (Davis \& Park, 1961) with Aeromonas spp. in a single genus, but the distinctive morphology that Vibrio species display and the absence of cross reactions between the soluble antigens of the two genera (Caselitz, 1960) makes the author hesitate to do this; others may be bolder. Certain Aeromonas strains are capable of growing on media such as Aronson agar and Dieudonné medium, usually considered to be selective for Vibrio, and some are sensitive to the phosphate derivative of the vibriostatic compound described by Shewan et al. (1954) and Rhodes (1959). Somatic curvature and also fermentation of carbohydrates without gas production, both sometimes considered to be diagnostic of Vibrio, are features of some Aeromonas strains. In view of the similarities between the two genera, one wonders whether some of the 'vibrios' studied by Taylor, Pandit \& Read (1937), Jackson (1948) and others were Aeromonas spp. It appears that the methods used for isolating and identifying the 'vibrios' would not have excluded Aeromonas. It is, in fact, difficult to define Aeromonas and Vibrio in such a way as to make them mutually exclusive, as will be obvious from a comparison of the results reported here for Aeromonas with those reported by Davis \& Park (1961) for Vibrio.

Note. Dr B. P. Eddy of the Low Temperature Research Station, Cambridge, and Dr K. J. Steel of the National Collection of type cultures have drawn the author's attention to the work of Clement \& Gibbons (1960). Clement and Gibbons (1960) reclassified Aeromonas hydrophila strains NCIB 8529 and NCIB 8530 as Aerobacter cloacae because the organisms were peritrichate and differed from 'authentic' Aeromonas in several biochemical characters. The fact that the kind of flagellation displayed by these strains was not typical of Aeromonas is also recorded in the present paper. The strains were retained for study because many organisms that were possibly polarly flagellate were observed (e.g. Pl. 1, fig. 8). It was thought that strains 8529 and 8530 were showing a variation in flagellar pattern similar to that reported by Leifson \& Hugh (1953) to occur in several members of the genus Aeromonas including one of the type cultures of $A$. hydrophila (i.e. ATCC 7965) considered by Clement \& Gibbons (1960) to be authentic. While the work of Clement \& Gibbons (1960) shows that strains 8529 and 8530 are more satisfactorily classified as Aerobacter cloacae than as Aeromonas hydrophila, it should be remembered that several of the biochemical characters are said by these authors to differentiate 8529 and $\mathbf{8 5 3 0}$ from 'authentic' Aeromonas known to be possessed by some polarly flagellate fermentative bacteria (see Eddy, 1960; Park, present paper).

\section{Pseudomonas}

The possession by a polarly flagellate Gram-negative rod of the ability to oxidize carbohydrates and/or to produce compounds that fluoresce under u.v. radiation is thought by the author to be sufficient to justify its classification as Pseudomonas. Forty strains studied in this work had both these characteristics; none was found with one but not the other character. Thornley (1960), who examined oxidative, 
polarly flagellate rods for their ability to produce u.v.-fluorescent compounds on a proteose-peptone + glycerol + salts medium, found that only about one-third of her strains had this ability. It is not known whether the results obtained on the medium she used are strictly comparable with those obtained on glucose + chalk medium used in the present studies, but it does appear that completely non-u.v.fluorescent Pseudomonas do occur. Neither Bergey's Manual (1957) nor Sherris et al. (1959) considered that pigment production should be relied upon for identifying Pseudomonas bacteria. However the presence of a green diffusible fluorescent pigment in cultures of polarly flagellate Gram-negative rods is generally regarded as being indicative of Pseudomonas. Although Rhodes (1959) used this character in isolating her Pseudomonas strains, she concluded because of reports of production of fluorescent pigments, not fluorescin, by Azotobacter (Johnstone, 1955) andBacillus subtilis (Shank, Chmura \& Silliker, 1958) that this character had no diagnostic value. The present author thinks that the ability to produce u.v.-fluorescent compounds is of diagnostic value when positive, if used in conjunction with other characters such as polar flagellation.

Other reactions given by the Pseudomonas strains studied are shown in Table 2. Generally these agree with those given for Pseudomonas by Seleen \& Stark (1948) Rhodes (1959) and others. The ability to utilize various aromatic compounds as sole carbon source is a property that the author has found to be common in the genus.

The arginine tests described by Sherris $e t$ al. (1959) and by Thornley (1960) were not used with the organisms studied here. It seems that these tests are of considerable value in distinguishing between Pseudomonas and peritrichously or nonflagellate bacteria, but of less value in separating Pseudomonas from other polarly flagellate bacteria between which there appear to be only quantitative differences.

The separation of Pseudomonas aeruginosa from other members of the genus on the basis of temperature requirements for growth and on the production of pyocyanine now seems well established (Seleen \& Stark, 1943; Haynes, 1951). All the Pseudomonas strains studied here that were capable of growth at $42^{\circ}$ also produced pyocyanine and these were classified as $P$. aeruginosa. As can be seen from Table 3 , certain other properties were more common in this species than in the $\boldsymbol{P}$. ftuorescens strains studied. No $P$. aeruginosa strains were isolated from water. The gluconate test of Haynes (1951), the oxidase test of Kovacs (1956) and the cytochrome oxidase test of Gaby \& Hadley (1957), all of which were developed to distinguish $\boldsymbol{P}$. aeruginosa from other Gram-negative bacteria found in clinical material, gave positive results with some $\boldsymbol{P}$. fluorescens strains also. Although the two species show many common characteristics (see also Rhodes, 1959), as one would hope, since they are classified in the same genus, there appears to be little chance of confusing them, even if pyocyanine production is ignored. The studies of $\operatorname{Liu}(1961 b)$ on the serology of extracellular antigens produced by various Pseudomonas strains, in which it was found that $\boldsymbol{P}$. aeruginosa strains had a species specific antigen, confirmed that the two species are distinct.

The success in separating $P$ seudomonas aeruginosa from $\boldsymbol{P}$. fluorescens on the basis of the upper temperature limit for growth made it tempting to subdivide $\boldsymbol{P}$. fluorescens on the ability to grow at $0^{\circ}$. While there was no other characteristic correlating with growth at $0^{\circ}$, separation on this basis led to two groups which showed marked differences in the distribution of positive results to various tests. It is 
appreciated that the number of strains involved is small and the results possibly not significant. The separation is mentioned in the hope that others will carry out tests to determine the ability of their $\boldsymbol{P}$. fluorescens strains to grow at $0^{\circ}$, to utilize phenol when supplied at $0.05 \%(\mathrm{w} / \mathrm{v})$, and to utilize catechol and benzoic acid. Perhaps, as Jakoby, Schatz, Hutner \& Weber (1952) suggested, pseudomonads can be classified on their ability to utilize various aromatic compounds.

Table 3. Percentage of strains in each of three groups of Pseudomonas that gave positive results in various tests

\begin{tabular}{|c|c|c|c|}
\hline Test & $\begin{array}{l}P . \text { aeruginosa } \\
10 \text { strains }\end{array}$ & $\begin{array}{l}\text { P. fluorescens (1) } \\
21 \text { strains }\end{array}$ & $\begin{array}{l}\text { P. fluorescens (2) } \\
\text { 9 strains }\end{array}$ \\
\hline $\begin{array}{l}\text { Pyocyanine production } \\
\text { Growth at } 42^{\circ} \\
\text { Growth at } 0^{\circ} \\
\text { Growth in } 6 \%(\mathrm{w} / \mathrm{v}) \mathrm{NaCl}\end{array}$ & $\begin{array}{r}100 \cdot 0 \\
100 \cdot 0 \\
0 \cdot 0 \\
100 \cdot 0\end{array}$ & $\begin{array}{r}0.0 \\
0.0 \\
100.0 \\
0.0\end{array}$ & $\begin{array}{l}0.0 \\
0 \cdot 0 \\
0.0 \\
0 \cdot 0\end{array}$ \\
\hline $\begin{array}{l}\text { Utilization of: } \\
\text { fructose } \\
\text { sucrose } \\
\text { mannitol } \\
\text { tryptophan } \\
\text { benzoate } \\
\text { catechol } \\
\text { phenol }\end{array}$ & $\begin{array}{r}0 \cdot 0 \\
0 \cdot 0 \\
80 \cdot 0 \\
90 \cdot 0 \\
100 \cdot 0 \\
90 \cdot 0 \\
0 \cdot 0\end{array}$ & \begin{tabular}{r|}
$\mathbf{3 3} \cdot 8$ \\
$\mathbf{3 3 \cdot 3}$ \\
$52 \cdot 4$ \\
$57 \cdot 1$ \\
$47 \cdot 6$ \\
$4 \cdot 8$ \\
$0 \cdot 0$
\end{tabular} & \begin{tabular}{r|}
$11 \cdot 1$ \\
$0 \cdot 0$ \\
$0 \cdot 0$ \\
$22 \cdot 2$ \\
$100 \cdot 0$ \\
$100 \cdot 0$ \\
$88 \cdot 8$
\end{tabular} \\
\hline $\begin{array}{l}\text { Attack on: } \\
\text { starch } \\
\text { gelatin } \\
\text { casein } \\
\text { serum } \\
\text { Reduction of nitrate } \\
\text { More than } 3 \text { flagella/organism }\end{array}$ & $\begin{array}{r}0 \cdot 0 \\
100 \cdot 0 \\
100 \cdot 0 \\
80 \cdot 0 \\
90 \cdot 0 \\
10 \cdot 0\end{array}$ & $\begin{array}{r}47 \cdot 6 \\
90 \cdot 5 \\
4 \cdot 8 \\
9 \cdot 5 \\
19 \cdot 1 \\
71 \cdot 4\end{array}$ & $\begin{array}{r}22 \cdot 2 \\
0 \cdot 0 \\
0 \cdot 0 \\
0 \cdot 0 \\
0 \cdot 0 \\
77 \cdot 8\end{array}$ \\
\hline
\end{tabular}

\section{Comamonas}

Several of the organisms studied here gave negative results in most of the tests used, and because of this they were considered to be members of a single group. It is thought that the group is sufficiently distinct from either Aeromonas or Pseudomonas to merit generic rank. It is not possible to decide on present evidence whether one or more species is represented. There is, however, a gradation in characteristics shown by members of this genus that at the more active extreme suggests a relationship with Pseudomonas (see also Davis \& Park, 1961). Four strains studied (author's nos. 32, 33, 34, 36) were most striking in this respect. They did not produce excess acid from carbohydrates supplied in complex media, either because other compounds were utilized preferentially or because there were no acidic end products of carbohydrate attack, but they were capable of utilizing some carbohydrates as sole carbon source. They also showed an ability to utilize a number of other organic compounds as sole carbon sources.

The Comamonas strains studied all possessed one or occasionally 2 flagella at one pole and in this way they differed from Lophomonas (Galarneault \& Leifson, 1956) which was described as having a tuft of from 2 to 4 flagella at one or both poles. There is a need to classify polarly flagellate strains which resemble Alcaligenes in giving negative reactions to many biochemical tests, separately from other morphologically similar types. Lehmann \& Neumann (1931) included such forms in 
a single species, Vibrio alcaligenes; but this is not a satisfactory arrangement since they differ from the type species, V. comma, both in their morphology and physiology, (see Davis \& Park, 1961). Galarneault \& Leifson (1956) intended the genus Lophomonas for those bacteria physiologically like Alcaligenes that had more than one polar flagellum, monotrichous forms being retained in Pseudomonas (Leifson, 1958). They claimed that $L$. alcaligenes was synonymous with $V$. alcaligenes (Lehmann \& Neumann) but this was not so since the latter species was originally defined as consisting of organisms having from 1 to 6 polar flagella. Davis \& Park (1961) pointed out that the name Lophomonas is invalid and they substituted the name Comamonas. The author can see no reason for excluding those bacteria of the Alcaligenes type having predominantly only one polar flagellum from similar but lophotrichous forms and he therefore considers that the genus Comamonas should include all those polarly flagellate Gram-negative rods physiologically similar to Alcaligenes that do not display a typical Vibrio morphology (Park, 1961; Davis \& Park, 1961).

I wish to thank Dr G. H. G. Davis for the help and encouragement he has given me during the preparation of this paper, and Mr C. C. Newton for his technical assistance with the electron microscope. The gift of a sample of compound 0/129 from Dr P. F. D'Arcy of Allen \& Hanburys Ltd. is gratefully acknowledged.

\section{REFERENCES}

Adams, J. N., Wiluiams, J. \& Payne, W. J. (1961). Agarbacterium alginicum: the appropriate taxonomic designation for Alginomonas alginica. J. Bact. 81, 162.

Bartholomew, J. W. (1949). Flagellation of certain species of Pseudomonas as seen with the electron microscope. J. gen. Microbiol. 3, 340.

Bergey's Manual of Determinative Bacteriology (1957). 7th ed. Edited by R. S. Breed, E. G. D. Murray and N. R. Smith. London: Ballière, Tindall and Cox.

Bisset, K. A. (1951). The development of the surface structures in dividing bacteria. J. gen. Microbiol. 5, 155.

Boyce, R. W. \& Hill, C. A. (1900). A classification of the micro-organisms found in water. J. Path. Bact. 6, 32.

Caselitz, F. H. (1960). Antihämolysinstudien und ihre differentialdiagnostische Bedeutung für die Aeromonasgruppe. Z. Tropenmed. Parasit. 11, 469.

Clement, M. T. \& Gibbons, N. E. (1960). Aeromonas hydrophila (Pseudomonas hydrophila) NRC 491 and NRC 492 established as Aerobacter cloacae. Canad. J. Microbiol. 6, 591.

ConN, H. J. \& Worfe, G. E. (1938). The flagellation of bacteria. Science, 87, 283.

Corberi, E. \& Solatin, A. (1960). Osservazioni sulla microflora delle acque del Lago Maggiore. Ann. Microbiol. Enzimol. 10, 36.

CorNwall, J. W. (1914). The classification of bacteria for the purpose of water analysis. Indian J. med. Res. 2, 352.

Crawford, I. P. (1954). A new fermentative pseudomonad, Pseudomonas formicans, n.sp. J. Bact. 68, 734.

Davis, G. H. G. \& PARK, R. W. A. (1961). A taxonomic study of certain bacteria currently classified as Vibrio species. J. gen. Microbiol. 27, 101.

EDDY, B. P. (1960). Cephalotrichous, fermentative Gram-negative bacteria: the genus Aeromonas. J. appl. Bact. 23, 216.

EdDy, B. P. \& Kitchell, A. G. (1959). Cold-tolerant fermentative Gram-negative organisms from meat and other sources. J. appl. Bact. 22, 57.

Ewrive, W. H. \& JoHnson, J. G. (1960). The differentiation of Aeromonas and C27 cultures from Enterobacteriaceae. Int. Bull. bact. Nomencl. 10, 223. 
Fuller, G. W. \& Johnson, G. A. (1899). On the differentiation and classification of water bacteria. J. exp. Med. 4, 609.

Gaby, W. L. \& Hadley, C. (1957). Practical laboratory test for the identification of Pseudomonas aeruginosa. J. Bact. 74, 356.

Galarneault, T. P. \& Leirson, E. (1956). Taxonomy of Lophomonas n.gen. Canad. J. Microbiol. 2, 102.

Georgia, F. R. \& Poe, C. F. (1931). Study of bacterial fluorescence in various media. 1. Inorganic substances necessary for bacterial fluorescence. J. Bact. $22,349$.

Gray, E. (1951). The ecology of the bacteria of Hobson's brook, a Cambridgeshire chalk stream. J. gen. Microbiol. 5, 840.

HAYNes, W. C. (1951). Pseudomonas aeruginosa-its characterization and identification. J. gen. Microbiol. 5, 939.

HUGH, R. \& LeIfson, E. (1953). The taxonomic significance of fermentative versus oxidative metabolism of carbohydrates by various Gram-negative bacteria. J. Bact. 66, 24.

JACKson, R. (1948). The incidence and character of vibrios in British waters. J. gen. Microbiol. 2, 239.

JAKobY, W. B., Schatz, A., Hutner, S. H. \& WeBer, M. M. (1952). Interchangeability of quinolinic and nicotinic acids as growth factors for a pseudomonad oxidizing nicotinic acid. J. gen. Microbiol. 6, 278.

Jomsstone, D. B. (1955). Azotobacter fluorescence. J. Bact. 69, 481.

Jondan, E. O. (1903). The kinds of bacteria found in river water. J. Hyg., Camb. 3, 1.

Khambata, S. R. \& Bhat, J. V. (1953). Studies on a new oxalate-decomposing bacterium, Pseudomonas oxalaticus. J. Bact. 66, 505.

KluYver, A. J. \& Niel, C. B. van (1936). Prospects for a natural system of classification of bacteria. Zbl. Bakt. (2 Abt.) 94, 369.

Kovacs, N. (1956). Identification of Pseudomonas pyocyanea by the oxidase reaction. Nature, Lond. 178, 703.

Kulp, W. L. \& Borden, D. G. (1942). Further studies on Proteus hydrophilus, the etiological agent in 'Red leg' disease of frogs. J. Bact. 44, 673.

Lehmann, K. B. \& Neumann, R. O. (1931). Bacteriology Especially Determinative Bacteriology. 7th ed. English translation by R. S. Breed. New York: Stechert.

Leifson, E. (1958). Identification of Pseudomonas, Alcaligenes and related bacteria. Zbl. Bakt. (I. Abt. Orig.) 173, 487.

LEIFSON, E. \& HUGH, R. (1958). Variation in shape and arrangement of bacterial flagella. J. Bact. 65, 263.

LrU, P. V. (1961 $a)$. Observations on the specificities of extracellular antigens of the genera Aeromonas and Serratia. J. gen. Microbiol. 24, 145.

LIU, P. V. (1961 $b$ ). Identification of pathogenic pseudomonads by extracellular antigens. J. Bact. 81, 28.

Mrues, A. A. \& Halnan, E. T. (1937). A new species of micro-organism (Proteus melanovogenes) causing black rot in eggs. J. Hyg., Camb. 37, 79.

Mrues, E. M. \& Mrues, A. A. (1951). The identity of Proteus hydrophilus Bergey et al. and Proteus melanovogenes Miles \& Halnan, and their relation to the genus Aeromonas Kluyver \& van Niel. J. gen. Microbiol. 5, 298.

OrcuTt, F. S. \& NuTTING, L. A. (1942). The possibility of false interpretations in tests for acid production from carbohydrates due to peptone decomposition. J. Bact. 44, 147 .

PARK, R. W. A. (1961). A note on the systematic position of Vibrio fetus. J. appl. Bact. 24.

Pivnick, H. (1955). Pseudomonas rubescens, a new species from soluble oil emulsions. J. Bact. 70, 1.

Pivnick, H. \& Sabina, L. R. (1957). Studies of Aeromonas formicans Crawford comb. nov. from soluble oil emulsions. J. Bact. 73, 247.

Rrodes, M. E. (1958). The cytology of Pseudomonas spp. as revealed by a silver-plating staining method. J. gen. Microbiol. 18, 639.

RHodes, M. E. (1959). The characterization of Pseudomonas fluorescens. J. gen. Microbiol. 21, 221. 
Seleen, W. A. \& Stark, C. N. (1943). Some characteristics of green-fluorescent pigmentproducing bacteria. J. Bact. 46, 491.

Shank, J. L., Chmura, N. W. \& Siluiker, J. H. (1958). The production of fluorescent pigment by Bacillus subtilis. Bact. Proc. p. 11.

Shaw, C. \& Clarke, P. H. (1955). Biochemical classification of Proteus and Providence cultures. J. gen. Microbial. 13, 155.

Sherris, J. C., Shoesmith, J. G., Parker, M. T. \& Breckon, D. (1959). Tests for the rapid breakdown of arginine by bacteria: their use in the identification of pseudomonads. J. gen. Microbiol. 21, 389.

Shewan, J. M., Floodgate, G. D. \& Hayes, P. R. (1958). A national type culture collection of marine bacteria. Nature, Lond. 182, 1423.

Shewan, J. M., Hodgkiss, W. \& Liston, J. (1954). A method for the rapid differentiation of certain non-pathogenic, asporogenous bacilli. Nature, Lond. 173, 208.

Shimweld, J. L., Carr, J. G. \& Rhodes, M. E. (1960). Differentiation of Acetomonas and Pseudomonas. J. gen. Microbiol. 23, 283.

Simon, R. D. (1956). The use of fermentation reactions and pigment production to differentiate between types of Pseudomonas pyocyanea and other Pseudomonas species, especially fluorescens. Brit. J. exp. Path. 37, 494.

Sneath, P. H. A. (1956). The change from polar to peritrichous flagellation in Chromobacterium spp. J. gen. Microbiol. 15, 99.

Sneath, P. H. A. (1957). Some thoughts on bacterial classification. J. gen. Microbiol. 17, 184.

Stevengon, J. P. (1959). A note on the genus Aeromonas. J. gen. Microbiol. 21, 366.

TAYLon, C. B. (1942). Bacteriology of fresh water. III. The types of bacteria present in lakes and streams and their relationship to the bacterial flora of soil. J. Hyg., Camb. 42, 284.

TAylor, J., Pandit, S. R. \& Read, W. D. B. (1937). A study of the vibrio group and its relation to cholera. Indian $J$. med. Res. 24, 931.

Thomas, S. B., Hobson, P. M. \& Druce, R. G. (1959). Coli-aerogenes bacteria in farm water supplies. J. appl. Bact. 22, 32.

Thomas, S. B. \& Thomas, B. F. (1955). The bacteriology of farm water supplies: a study of the colony count in 72 hours at $22^{\circ}$. J. appl. Bact. 18, 312.

Thorntey, M. J. (1960). The differentiation of Pseudomonas from other Gram-negative bacteria on the basis of arginine metabolism. J. appl. Bact. 23, 37.

WARD, M. H. (1897). Fifth report to the Royal Society Water Research Committee. Proc. roy. Soc. 61, 415.

Wetmore, P. W. \& Gochenour, W. S. (1956). Comparative studies of the genus Malleomyces and selected Pseudomonas species. I. Morphological and cultural characteristics. J. Bact. 72, 79.

\section{EXPLANATION OF PLATE}

All figures are electron micrographs of gold-palladium shadowed specimens.

Fig. 1. Aeromonas sp. (strain 1). The organism is dividing and has a flagellum at one pole only. $\times \mathbf{1 5 , 5 0 0 .}$

Fig. 2. Pseudomonas aeruginosa (strain 42). The organism has many flagella at one pole and none at the other. It is dividing. $\times 10,500$.

Fig. 3. Organisms of a strain that was not studied in detail showing degenerate peritrichous flagellation. $\times 8,500$.

Fig. 4. $P$. aeruginosa (strain 81). Organisms with single polar flagella. $\times 10,500$.

Fig. 5. P. fluorescens (strain 71). A dividing organism with flagella at one pole only. $\times 10,500$.

Figs. 6, 8. A. hydrophila. Two of the kinds of flagellar arrangement observed in the cultures examined.

Fig. 6. A. hydrophila (NCIB 8529). $\times 6,500 . \quad$ Fig. 8. A. hydrophila $(\mathrm{NCIB} 8530) . \times 8,500$.

Fig. 7. P. fluorescens (strain 112). Showing variation in the number of flagella possessed by different organisms in the same culture. $\times 5,000$. 
Journal of General Microbiology, Vol.27, No. 1

Plate 1

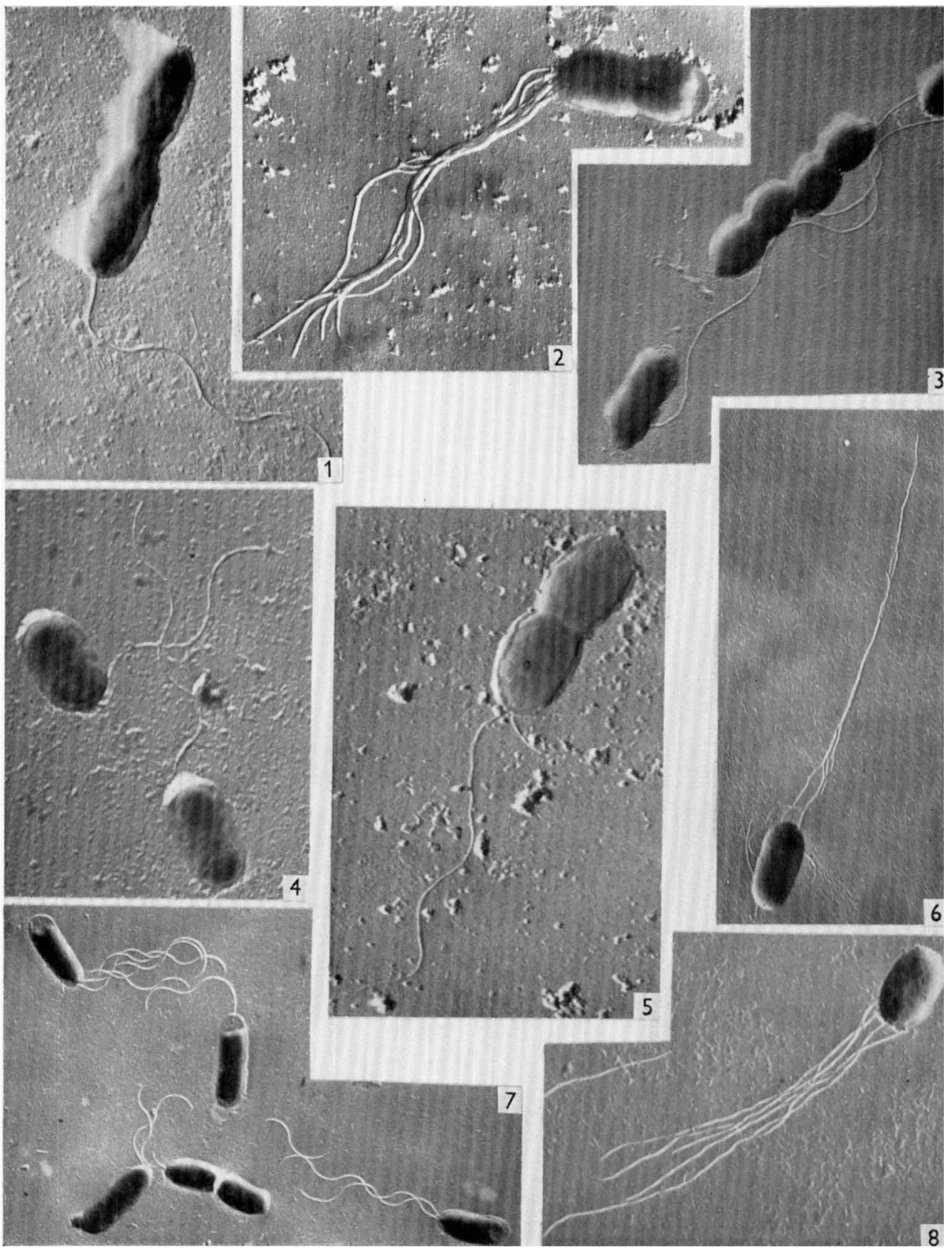

R. W. A. PARK

(Facing p. 133) 